\title{
Research on the Application of Interactive Teaching in Education Teaching of Computer Profession
}

\author{
Dongjie Jiao ${ }^{1, a^{*}}$ and Bingxin Zhou ${ }^{1, b}$ \\ ${ }^{1}$ LuoHe Medical College, Henan Province \\ a86852503@qq.com, b540979075@qq.com
}

Keywords: Computer profession; Education and teaching; Interactive teaching effective strategy; Applied research

\begin{abstract}
In recent years, with the rapid development of science and technology and the popularization of computer technology, the traditional education teaching mode of China's computer profession is no longer in line with the modern teaching philosophy. Therefore, the application of interactive teaching mode in the computer profession education teaching has become an inevitable trend of contemporary education reform. In computer applying interactive teaching mode in vocational education teaching, can not only optimize the college computer teaching way, the computer technology and classroom teaching both organic unifies in together, can make originally boring computer professional teaching classroom became more vivid, thus enriching the content of computer professional teaching, and increase the attraction, broaden the width of the computer professional teaching and field of vision, to a certain extent, to mobilize students' learning interest and enthusiasm of computer knowledge, so that the students really love learning computer, students can give full play to their initiative and enthusiasm, actively communicate with the teacher, Share the learning results, improve the quality of computer teaching and students' independent learning ability. Therefore, interactive teaching plays a huge role in education teaching of computer profession in China's colleges and universities. It also makes up for the existing problems and defects in the traditional computer profession education teaching process to some extent. Based on the current situation and problems of interactive teaching application in computer vocational education teaching, this paper puts forward some effective measures and Suggestions to promote the development of computer teaching in China's colleges and universities.
\end{abstract}

\section{Introduction}

At the present stage, the Internet has entered thousands of households. We have been in an information technology era. With the gradual popularity of the Internet, the computer profession education teaching has gradually become the main way of teaching in China's colleges and universities. Computer vocational education emphasizes interactive and comprehensive treatment of multiple sensory media, featuring integration, diversity and interactivity. Therefore, the application of interactive teaching mode in computer profession education teaching complies with the actual work of computer teaching, which can greatly relieve the teachers' teaching pressure, make great changes to the traditional computer profession education teaching mode, and promote the improvement of education level in China. This paper deeply analyzes the importance and necessity of interactive teaching in computer profession education teaching, which plays a very important role in perfecting our education system.

\section{The Specific Connotation and Advantages of Interactive Teaching at the Present Stage}

The origin of the word interaction is the computer, which belongs to the term of computer science. It refers to the dynamic process in which the computer system receives the terminal, processes the analysis, and then returns the result to the computer terminal. Will interact the vocabulary used in the teaching, to form the interactive teaching mode, this mainly refers to the teachers and students in the classroom interaction, the interaction and communication between students and students, the classroom learning common mining resources, realizes the resource sharing, so as to improve the 
classroom learning enthusiasm and initiative of students, for students to create a good learning environment. Advantage of interactive teaching is, in the process of communication between teachers and students and students of communication, can find the advantages and disadvantages of students themselves adequately, can grasp the students' learning and master the situation of knowledge, not only exercise the student's own power of expression, also can let the teacher found problems, and guide students to correct mistakes, improve the efficiency of classroom teaching, real play to the potential advantages of interactive teaching.

\section{Current Situation and Existing Problems of Education Teaching Class for Computer Profession in China}

Computer profession education teaching method is dry, mode is unitary: There are many college simply equate computer professional teaching mode with the traditional classroom teaching mode, in the process of computer teaching of vocational education is often confined to the teacher unilateral teaching, too much emphasis on teaching and learning, just let the students watch courseware and books blindly, made the knowledge of the computer, thus ignore the teachers and students of communication, play an exemplary role.

Computer professional education teaching conservative ideas, lack of communication Current: college computer teaching of vocational education is mainly rely on classroom teaching time, few students after-school practice, traditional computer professional teaching in the classroom, students can only rely on listening to the teacher to obtain knowledge and language awareness, no actual hands-on operation, between teachers and students, a serious lack of communication between students and students, not form a good learning atmosphere, for example: the teacher just through like a student demonstration operation process, and did not give students questions time and time of the communication.

\section{The Effective Strategy of Using Interactive Teaching Method in Computer Profession Education Teaching.}

Interactive teaching is carried out by the method of scenario reproduction: Computer professional teaching teachers can in the computer by using the scene representation method in classroom teaching, by restoring the practical problems encountered in the process of computer operation, lets the student doing and saying the exchange, together to solve the problem, it can not only enable students to master the computer knowledge in the relaxed happy atmosphere, also can be used as a dose of refreshment stimulating the enthusiasm of students to learn computer. By making students immerse themselves and reproduce the contents of the computer textbooks, students will be motivated to learn the computer and develop the good habit of carefully listening to lectures under the subtle influence. In the process of actual operation and hands-on, students can be familiar with computer knowledge, so as to improve the teaching schedule, at the same time, teachers and students, between students and students can also interact, teachers can ask students, students according to the previous operations and prepare to answer this question, this book knowledge of computer memory yield twice the result with half the effort. The method of scenario reproduction can not only stimulate students' interest in learning computer, but also improve the classroom teaching effect of computer professional education teaching.

Group cooperation method is used for interactive learning: Group cooperation is a common teaching method in education class. Students can be divided into several people a group, jointly solve the problem of computer, the interactive teaching can not only stimulate students' imagination and creativity, but also can enhance students' team consciousness, in the case of unconsciously, into the teaching of computer professional, greatly to mobilize students' learning initiative of the computer, so as to optimize computer class effect.

Using scene integration method, optimize the effect of computer classroom teaching: As Einstein said, "imagination is far more important than knowledge. Knowledge is limited while imagination is infinite. It can be seen that one's imagination is very rich. Computer vocational 
teachers can use the method of scene integration in the computer classroom teaching process to conduct two-way interaction. In this way, students can not only improve their enthusiasm to learn computer knowledge and arouse their motivation to learn computer, but also build a harmonious and equal relationship between teachers and students, so that students are fully willing to communicate with teachers and answer questions, so as to optimize the classroom teaching effect of computers.

Carry out interactive teaching mode and build harmonious teacher-student relationship: Good classroom interaction is an important part of computer classroom teaching and also an important way to build a harmonious relationship between teachers and students. Teachers can arrange classroom interaction in computer teaching with different characteristics of students. First, teachers can increase classroom interaction by demonstrating the process of computer operation. Teachers can operate step by step and students can follow step by step. Secondly, the teacher can also carry out necessary classroom interaction through body language. For example, in the process of actual operation, if the student does well, the teacher can make the expression of intoxication; if the student doesn't operate well, the teacher can make the gesture of cheering to encourage the student. Finally, the teacher can take the way of classroom question, by letting the student answer the computer question, corrects the student's wrong viewpoint, guides the student to establish the correct study method. All methods above is helpful for teachers in the computer professional teaching and students to interact, thus to build a harmonious equal relationship between teachers and students, the students can not only the traditional passive listening to lectures, passive learning style into students' autonomous learning, give full play to the superiority of interactive mode, still can make students better grasp of computer knowledge, but also can improve the effect of classroom teaching computer, so that the students love computer this subject.

\section{Summary}

To sum up, in the computer application of interactive teaching mode in teaching vocational education is an inevitable trend in the development of science and technology today, using the new type of interactive teaching mode can improve the utilization efficiency of computer professional teaching classroom, can improve students' thinking ability and practical ability, to mobilize students' rich imagination, achieve the goal of optimization of the traditional teaching mode. In short, the advantages of using interactive teaching methods in computer vocational education teaching are obvious, which requires the joint efforts of schools, students and educators.

\section{References}

[1] S.Yang. Discussion on the application of multimedia technology in computer remote education [J]. Computer knowledge and technology; 2011 (21).

[2] P.Yang. Discussion on problems and countermeasures of remote computer education [J]. Information and computers (theoretical edition); 2012 (9).

[3] L.P.Chen . Research on English teaching model in junior high school based on project teaching method [J]. Journal of jiamusi education college; 2012 (2). 